UDK 37.018.43:004.738.5

Prethodno saopštenje

Primljeno: 25.2.2019.

Odobreno za štampu: 5.7.2019.

DOI: https://doi.org/10.46630/gped.1.2019.06

\title{
DIGITALNA KOMPETENTNOST ADOLSECENATA
}

\author{
Aleksandra Jovanović ${ }^{1}$ \\ Univerzitet u Nišu, Filozofski fakultet, Departman za pedagogiju (student DAS) \\ Maja Kostadinović \\ Univerzitet u Nišu, Filozofski fakultet, Departman za komunikologiju i novinarstvo \\ (student DAS)
}

\begin{abstract}
Apstrakt: U radu se razmatra značaj digitalne kompetentnosti adolescenata. Život današnjice obeležen je tehničko-tehnološkim rešenjima koja prate svaku oblast čovekovog života i rada. Da bi koristio internet i njegove sadržaje korisnik mora pokazati makar minimum znanja koja mu omogućavaju snalaženje u digitalnom svetu. Ovaj 'najdemokratičniji medij' pruža mogućnost svakome da u bilo kom trenutku vidi i plasira različite sadržaje. Internet postaje moćno oružje različitih propagandnih uticaja. Analizom stavova 222 adolescenta razmatramo da li upotreba interneta njihov život čini kvalitetnijim, koliko je razvijena svest o bezbednosti korišćenja interneta, kao i da li su digitalno kompetentni. Razmatra se prisutnost vređanja na internetu, opreznosti, zaštite privatnosti, ugrožavanja bezbednosti, širenja dezinformacija, poštovanja drugih, ugrožavanja privatnosti, obazrivosti na internetu. Rezultati su pokazali da adolescenti smatraju da internet njihov život čini kvalitetnijim kao i da su bezbedni na internetu. Sve ovo potvrđuje da su adolescenti 'digitalni urođenici', kao i da poseduju digitalne kompetencije. Ipak, i pored toga je neophodno sprovođenje programa medijskog obrazovanja koji će razviti kritičku svest i osposobiti adolescente da prepoznaju različite pokušaje da se kroz sadržaje plasiraju ideje, utiče na mišljenje i podstakne na akcije koje mogu ugroziti prava drugih.
\end{abstract}

Ključne reči: digitalne kompetencije, bezbednost na internetu, digitalno nasilje, kritička pedagogija, prevencija.

\section{Teorijski pristup problemu istraživanja}

\subsection{Mladi u virtuelnom svetu}

U savremenom dobu digitalni način komunikacije sve više zamenjuje komunikaciju licem u lice i postaje dominantan oblik razmene poruka i informacija. Preterano uranjanje u svet virtuelnog dehumanizuje mlade ljude, a izazovi digitalnog sveta su sve češći i opasniji. Poter (2011) ističe da decu treba tretirati kao posebne

\footnotetext{
${ }^{1}$ aleksandra.s.jovanovic.88@gmail.com
} 
korisnike medijskih poruka, s obzirom da ih nedostatak životnog iskustva i zrelosti može dovesti do neadekvatne obrade onoga što im se plasira putem medija. Informisanje internetske generacije je danas upitno, s obzirom da svako može kreirati i plasirati informaciju onlajn, a mladi kao digitalni urođenici brzo i lako konzumiraju informacije. Postavlja se pitanje pismenosti, odnosno razumevanja informacija. Vesti često same pronalaze mlade, bez da ih pretražuju, ali rezultati istraživanja navode na zaključak da mladi ne procenjuju kritički ono što im se plasira (Hrnjić-Kuduzović i sar., 2016).

Istraživanja pokazuju da preko $80 \%$ dece uzrasta od 8 do 17 godina ima pristup smart telefonu, kao i da preko 90\% domaćinstava poseduje laptop, tablet ili kompjuter i ima pristup internetu. Na mlađem uzrastu deca su prisutna na internetu oko sat vremena ili dva sata, a na starijem i više od tri sata (UNICEF, 2016). Sve ovo ukazuje na potrebu edukacije o bezbednoj upotrebi i obavezi roditelja da budu uz svoju decu kada koriste internet. Nemogućnost upotrebe interneta mlade naraštaje izoluje, onemogućava im neformalno obrazovanje, učenje u onlajn svetu i prostor da izraze sebe (UNICEF, 2017: 17).

Digitalnu kompetentnost nazivamo i digitalna pismenost, medijska pismenost, internet pismenost, kompjuterska pismenost, informacijska pismenost, funkcionalna pismenost, izvore pismenosti, upotrebu digitalnih alata, istraživačku pismenost, „objavljivačku“ pismenost, kritičku pismenost, tehnološku pismenost. Boden (Bawden, 2001), Gutjerez i Tajner (Gutiérrez \& Tyner, 2012) nazivaju je informacijska i digitalna pismenost. Podrazumeva znanje i specifična umeća koja nam omogućavaju da na internetu tražimo, dobijemo i širimo informacije, ali i da kritički i obazrivo svemu tome pristupamo. Definiše se kao „samopouzdano i kritičko korišćenje informacionih i komunikacionih tehologija za rad, odmor i komunikaciju" (Zakon o osnovama sistema obrazovanja i vaspitanja, 2018). Prepoznata je kao esencijalna veština savremenog društva, koja može rešiti društvene probleme (Gutiérrez \& Tyner, 2012: 37-38). Zahteva i motivaciju za učešće u digitalnoj kulturi (Ilomäki et al., 2011).

Ekstrovertna deca lako stvaraju onlajn prijateljstva, ali se pokazalo i da introvertna deca koriste internet kako bi ostvarivala socijalne kontakte, odnosno socijalnu kompenzaciju (Peter et al., 2005; UNICEF, 2017). Sama činjenica da su savremena deca od najranije dobi izložena digitalnoj tehnologiji, znači da brzo i lako savladavaju njenu upotrebu, ali ne znači da umeju bezbedno da je koriste. Možemo reći da su adolescenti delimično digitalno kompetentni ukoliko ne čine nasilje, ne vređaju druge, štite i poštuju sebe i druge.

Danas je među mladima zastupljen internet multitasking, odnosno obavljanje više aktivnosti odjednom na internetu. Adolescenti koriste internet za mnoge aktivnosti, a najčešće za igranje igrica, razmenu privatnih poruka, posećivanje sajtova. Internet postaje mesto eksperimentisanja sa sopstvenim identitetom. Često se adolescenti predstavljaju kao neko drugi, i najviše to čine iz šale ili da bi bili interesantniji drugima. Razmena poruka sa strancima je ređe zastupljena, već se uglavnom komunicira sa bliskim osobama, što je pozitivno jer se tako ne izlažu rizicima predatora. Nije pronađena korelacija između upotrebe interneta i osećaja zadovoljstva (Gross, 
2004). Istraživanje je pokazalo da adolescenti koji manje koriste medije imaju bolje ocene u školi. Takođe, roditelji deci postavljaju pravila upotrebe i namene mobilnih telefona. Internet se najviše koristi za društvene mreže (Rideout et al., 2010).

$\mathrm{Na}$ osnovu rezultata sprovedenih istraživanja možemo grupisati najčešće rizike na internetu: davanje privatnih podataka nepoznatim ljudima, isključivanje roditelja iz njihovog onlajn života; sve češće pristupanje internetu preko pametnih telefona; činjenje digitalnog nasilja, ali i trpljenje; nedostatak svesti o potrebi za zaštitom na internetu; ne traži se pomoć od roditelja i škole kada se digitalno nasilje desi; nedostatak edukacije roditelja kao primarnih modela ponašanja svoje dece o bezbednoj upotrebi interneta (Popadić i Kuzmanović, 2013).

\subsection{Digitalno nasilje}

$\mathrm{S}$ obzirom da se ne dešava licem u lice, stvara se privid da digitalno nasilje nije realno, ili da čak i nije nasilje nego šala, što svakako nije istina. Elektronsko nasilje i zlostavljanje je zloupotreba informacionih tehnologija koja može da ima za posledicu povredu i ugrožavanje dostojanstva i ličnosti i ostvaruje se slanjem audio i video poruka. Činjenje i vrste nasilja danas su klasifikovane na nivoe, bilo da se dešavaju licem u lice ili u digitalnom svetu. Digitalno nasilje se svrstava u tri nivoa: prvi nivo čine uznemiravajući pozivi, poruke i slike, drugi nivo čine snimanje i slanje video poruka, zloupotreba blogova, četova, snimanje i distribuiranje nasilnih ili omalovažavajućih videa i slika, i treći nivo čine snimanje i distribuiranje nasilnih i seksističkih scena (Pravilnik o protokolu postupanja u ustanovi u odgovoru na nasilje, zlostavljanje i zanemarivanje, 2010). Digitalno nasilje može biti direktno ili indirektno, odnosno druge osobe se mogu uključivati bez njihovog znanja. Najčešći oblici nasilja su postavljanje i snimanje uznemiravajućih slika i videa, uznemiravanje pozivima, lažno predstavljanje, krađa lozinki, laž, ismevanje, slanje virusa, ignorisanje osoba i govor mržnje (Kuzmanović i sar., 2016; Willard, 2007). Svaka škola mora imati svoj program prevencije i intervencije u slučajevima bilo kog vida nasilja. Međutim, rezultati pokazuju da su srednje škole angažovanije u iskorenjivanju nasilja, i više se bave prevencijom putem tribina, radionica, debata, promotivnih materijala. Aktivnosti o nenasilnoj komunikaciji su malo zastupljene u školama. Upoznavanje učenika sa postojanjem školskog tima koji se bavi problemima nasilja ukazuje im na obavezu da nasilje prijave. Škole se često odriču odgovornosti kada se nasilje ne desi u školi (Nešić, 2011). Digitalno nasilje se često dešava izvan škole, ali to ne znači da škola ne treba da reaguje ako su počinioci i žrtve njeni učenici, jer je koren nasilja upravo u njihovim odnosima koji se dešavaju u školi.

U digitalnom svetu javljaju se rizici od kontakata i rizici od ponašanja. Rizici od kontakata podrazumevaju rizične komunikacije gde se od deteta traži da učestvuje u nezdravim i opasnim ponašanjima. Rizike od ponašanja stvaraju sama deca, neadekvatno komunicirajući u onlajn prostoru. Kreiranje i deljenje sadržaja koji su diskrimantorni su čin digitalnog nasilja. Potrebno je razumeti da svako dete može biti izloženo digitalnom nasilju, ali i to da neće svako dete na njega reagovati na isti način (UNICEF, 2017: 22). 
Digitalno nasilje učestalije je od nasilja u realnom svetu i češće se dešava van škole nego u njoj. Uznemiravajući pozivi i poruke su najučestaliji oblik sajber nasilja među mladima. Čine ga jedna osoba ili grupa, a učestalost je od nedelju dana a nekad i duže. Osobe koje su žrtve fizičkog nasilja često su žrtve i digitalnog nasilja. Mnoge žrtve često ćute o digitalnom nasilju, ali je i onih koji o tome govore. Mladi navode da je blokiranje onih koji ih uznemiravaju na mreži vid odbrane. Snimanje i distibuiranje scena nasilja je ređe, ali ima najveći negativni uticaj na žrtve (Smith et al., 2008). Jedan od troje adolescenata je bar jednom godišnje uvredio nekoga na internetu. Preko 90\% je ostavljalo uvredljive komentare o nekome. Međutim, uvredljivi komentari ostavljaju se kao odgovor na provokaciju u većini slučajeva, a u nekim slučajevima adolescenti prvi vređaju. Percepcije adolescenata su da je vređanje na internetu zastupljeno često. Problemi u ponašanju i psihosocijalni problemi mladih rastu s porastom vređanja na internetu. Vređanjem drugih, mladi i sami postaju meta uznemiravanja. Dečaci više vređaju na internetu od devojčica (Ybarra \& Mitchell, 2007).

Adolescenti nikome ne govore o digitalnom nasilju, ili to čine uglavnom samo svojim prijateljima. Retko se o tome govori nastavnicima. Izjašnjavaju se da su više žrtve nego nasilnici i da se digitalno nasilje dešava uglavnom van škole. Uglavnom su žrtve video i audio distribucije snimaka. U školi je prisutnije nasilje putem tekstualnih poruka. Često se dešava da žrtve ne znaju ko je nasilnik, a u 50\% se dešava da je nasilnik iz iste škole kao i žrtva (Slonje \& Smith, 2008).

\subsection{Digitalna bezbednost i kritičko promišljanje}

Vodeći se načelima kritičke pedagogije da individua treba preispitivati svet oko sebe, kritički promatrati pojave i poruke koje svakodnevno prima putem interneta, najviše preko društvenih mreža ističe se značaj medijskog obrazovanja. S obzirom da je pametni telefon moćno i najčešće sredstvo u rukama mladih, sve informacije dostupne su im u svakom trenutku. Značaj medijskog obrazovanja koje treba programski inkorporirati od predškolskog do univerzitetsog obrazovanja, ogleda se u sposobnosti uočavanja uticaja medija na prenos informacija, oblikovanja kulture i moć, kritičko analiziranje povezanosti medijskih poruka i publike kojoj su namenjeni. Pravda i radikalna demokratija počivaju na mogućnosti slobodnog govora (Kellner \& Share, 2009). Ipak, sloboda ne znači i ugrožavanje prava drugih. Kritičko promišljanje treba da podstakne borbu za sopstvena prava, ali ne ugožavajući prava i slobode drugih različitih od nas. Digitalna bezbednost pretpostavlja digitalnu kompetentnost, ali korišćenje digitalne tehnologije ne podrazumeva digitalnu kompetentnost. Gudman (Goodman, 2003) ističe da dajući mogućnost mladima da sami budu kreatori digitalnih poruka, osim što postaju digitalno kompetentni, uče da se stave u poziciju drugog, sami kreiraju neku medijsku vest i plasiraju je na internetu, uče se produkciji lažnih vesti i time osvešćuju rizike rapidnog prenosa i uticaja informacija na mlade $u$ današnjem svetu.

Uloga roditelja u razvoju kritičke svesti je velika. Roditeljske brige prilikom upotrebe interneta usmerene su na komunikaciju sa nepoznatim ljudima, izloženost 
scenama nasilja, zloupotrebu ličnih podataka, sekusualno uznemiravanje i izloženost pornografskim sadržajima, trgovinu ljudima, izlaganje štetnim savetima, verskim ili zdravstvenim. Većina roditelja smatra da internet jeste „opasno mesto“, ali da njihova deca uglavnom nisu izložena rizicima. Najčešća aktivnost roditelja sa decom je razgovor o upotrebi interneta, ali su zastupljene i zajedničke aktivnosti upotrebe interneta. Preko $80 \%$ roditelja razgovara sa svojom decom o tome da druge ne treba vređati na internetu. Mali broj roditelja imao je iskustva neprijatnosti svoje dece na internetu. O internet bezbednosti samo $30 \%$ roditelja se informiše preko škole, a najviše preko prijatelja i televizije, što nije dobar podatak (UNICEF, 2016). Prevencija digitalnog nasilja je zastupljena od strane roditelja i škole, ali se pokazalo da devojčice pokazuju pozitivnije stavove o prevenciji, odnosno razgovorima sa roditeljima, obraćanju za pomoć, ulozi škole u prevenciji (Kostadinović i Jovanović, 2017).

Nedostatak svesti o posledicama sopstvenog ponašanja na internetu može nas obeležiti za ceo život. Digitalna bezbednost podrazumeva poznavanje i korišćenje određenih pravila u sajber prostoru. Pravila koja adolescenti treba da poznaju i poštuju u komunikaciji na mreži su: ne komunicirati o privatnim i intimnim stvarima sa nepoznatim ljudima; kada saznamo da smo na neki način prevareni, treba zatražiti pomoć; ne treba lagati i lažno se predstavljati na internetu; ne omalovažavati sebe i druge, ili otkrivati tuđu privatnost; biti obazriv prema informacijama koje dobijamo; sve što jednom postavimo na internetu može biti trajnog karaktera (Bogavac i Popadić, 2013).

Ipak, potrebno je istaći i prednosti onlajn komunikacije, odnosno informisanja, a to su: dostupnost - upotreba na bilo kom mestu; selektivnost - korisnik može birati šta čita i gleda; informativnost - mogućnost brzog dolaska do svih informacija; reverzibilnost - vraćanje na istu informaciju i njeno ponovno percipiranje; multimedijalnost - audio-vizelni format informacija i komunikacije; besplatnost-informacije i komunikacija se ne plaćaju, sem u nekim slučajevima; otvorenost - različiti vidovi i izvori informisanja, interaktivnost - objave, komentari, distribucija informacija (Hrnjić-Kuduzović, 2016: 113).

\section{Metodologija istraživanja}

Cilj istraživanja. Ispitati da li su adolescenti digitalno kompetentni, kao i da li stav adolescenata o uticaju upotrebe interneta na kvalitet života i stav o bezbednosti na internetu utiče na stavove o digitalnoj kompetentnosti. Digitalnu kompetentnost posmatramo kroz osam kategorija. Razmotriće se kakvi su stavovi o nasilju na internetu, neopreznosti na internetu, obazrivosti na internetu, ugrožavanju bezbednosti, neiskrenosti na internetu, zaštiti privatnosti, čuvanju digitalnih podataka.

Hipoteze istraživanja. Pretpostavlja se da su adolescenti digitalno kompetentni. Pretpostavlja se da stav adolescenata o kvalitetu života uz upotrebu interneta i stav o bezbednosti prilikom upotrebe interneta dovode do razlika u stavovima o digitalnoj kompetentnosti.

Varijable istraživanja. Nezavisne varijable istraživanja su stav učenika o kvalitetnijem životu uz upotrebu digitalne tehnologije i stav o bezbednosti prilikom 
upotrebe interneta. Zavisna varijabla je digitalna kompetentnost učenika, svrstana u osam kategorija dobijenih faktorskom analizom.

Prikupljanje podataka i uzorak istraživanja. Uzorak istraživanja čini 222 učenika uzrasta od 15 do 19 godina. Istraživanje je sprovedeno 2017. godine na teritoriji Nišavskog okruga. Istraživanje je realizovano na časovima odeljenjske zajednice. Učenici su imali oko petnaest minuta za popunjavanje instrumenta. Istraživanje je anonimno. Struktura uzorka prikazana je u Tabeli 1. Preko 70\% adolescenata smatra da upotreba interneta čini njihov život kvalitetnijim, kao i da su bezbedeni dok koriste internet.

Tabela 1. Struktura uzorka prema stavu o kvalitetnijem života uz upotrebu interneta i stavu o bezbednosti prilikom upotrebe interneta

\begin{tabular}{cccccc}
\hline $\begin{array}{c}\text { Kvalitet } \\
\text { Života }\end{array}$ & $\mathrm{f}$ & $\%$ & Bezbednost & $\mathrm{f}$ & $\%$ \\
\hline $\mathrm{da}$ & 198 & 89.2 & $\mathrm{da}$ & 159 & 71.6 \\
$\mathrm{ne}$ & 24 & 10.8 & ne & 63 & 28.4 \\
$\sum$ & 222 & $100 \%$ & $\sum$ & 222 & $100 \%$ \\
\hline
\end{tabular}

Instrument istraživanja. Kao instrument istraživanja korišćena je skala procene Likertovog tipa Digitalna kompetentnost (DK), konstruisana za potrebe ovog istraživanja. Skala se sastoji od dvadeset i pet ajtema, od kojih se petnaest ajtema obrnuto boduju, a na koje učenici odgovaraju sa: uopšte se ne slažem (1), ne slažem se (2), nisam siguran/na (3), slažem se (4), u potpunosti se slažem (5). Kronbah Alfa koeficijent iznosi .658. Faktorskom analizom, odnosno Varimaks rotacijom izdvojeno je osam faktora, osam kategorija digitalne kompetentnosti adolescenata, koji objašnjavaju $54.83 \%$ varijanse (Tabela 2 ).

Statistička obrada podataka. Rezultati istraživanja obrađeni su u programu SPSS 17.0. Koristio se Kronbah Alfa koeficijent, faktorska analiza, minimum, maksimum, aritmetička sredina i standardna devijacija, i Pirsonov Hi kvadrat test.

Tabela 2. Matrica strukture ekstrahovanih faktora

\begin{tabular}{|c|c|c|c|c|c|c|c|c|c|}
\hline \multirow{2}{*}{ 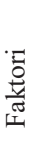 } & \multicolumn{3}{|c|}{ Inicijalne vrednosti } & \multicolumn{3}{|c|}{ Ekstrahovane vrednosti } & \multicolumn{3}{|c|}{ Rotirani faktori } \\
\hline & Ukupno & $\begin{array}{c}\% \\
\text { varijanse }\end{array}$ & $\begin{array}{c}\text { Kumulativni } \\
\%\end{array}$ & Ukupno & $\begin{array}{c}\% \\
\text { varijanse }\end{array}$ & $\begin{array}{c}\text { Kumulativni } \\
\%\end{array}$ & Ukupno & $\begin{array}{c}\% \\
\text { varijanse }\end{array}$ & $\begin{array}{c}\text { Kumulativni } \\
\%\end{array}$ \\
\hline 1 & 3,757 & 15,029 & 15,029 & 3,757 & 15,029 & 15,029 & 2,001 & 8,003 & 8,003 \\
\hline 2 & 1,920 & 7,679 & 22,708 & 1,920 & 7,679 & 22,708 & 1,865 & 7,460 & 15,463 \\
\hline 3 & 1,678 & 6,711 & 29,419 & 1,678 & 6,711 & 29,419 & 1,811 & 7,245 & 22,708 \\
\hline 4 & 1,436 & 5,745 & 35,164 & 1,436 & 5,745 & 35,164 & 1,771 & 7,086 & 29,793 \\
\hline 5 & 1,347 & 5,388 & 40,552 & 1,347 & 5,388 & 40,552 & 1,767 & 7,067 & 36,861 \\
\hline 6 & 1,238 & 4,952 & 45,504 & 1,238 & 4,952 & 45,504 & 1,739 & 6,957 & 43,817 \\
\hline 7 & 1,182 & 4,727 & 50,231 & 1,182 & 4,727 & 50,231 & 1,445 & 5,778 & 49,596 \\
\hline 8 & 1,150 & 4,599 & 54,830 & 1,150 & 4,599 & 54,830 & 1,309 & 5,234 & 54,830 \\
\hline 9 & 1,096 & 4,386 & 59,215 & & & & & & \\
\hline
\end{tabular}




\begin{tabular}{rrrr}
10 & 1,030 & 4,120 & 63,335 \\
11 &, 982 & 3,930 & 67,265 \\
12 &, 882 & 3,529 & 70,794 \\
13 &, 800 & 3,198 & 73,993 \\
14 &, 741 & 2,966 & 76,958 \\
15 &, 710 & 2,838 & 79,796 \\
16 &, 689 & 2,757 & 82,554 \\
17 &, 656 & 2,622 & 85,176 \\
18 &, 615 & 2,461 & 87,636 \\
19 &, 552 & 2,209 & 89,846 \\
20 &, 534 & 2,136 & 91,982 \\
21 &, 470 & 1,880 & 93,862 \\
22 &, 454 & 1,816 & 95,679 \\
23 &, 381 & 1,526 & 97,205 \\
24 &, 359 & 1,437 & 98,642 \\
25 &, 340 & 1,358 & 100,000 \\
\hline
\end{tabular}

Faktore, odnosno kategorije digitalne kompetentnosti smo grupisali prema srodnosti gde $\mathrm{u}$ obzir nisu uzimana faktorska zasićenja manja od 0,30 . Faktore smo imenovali na sledeći način: 1. Nasilje na internetu; 2. Privatnost i internet; 3 . Neopreznost na internetu; 4. Obazrivost na internetu; 5. Ugrožavanje bezbednosti na internetu; 6. Neiskrenost na internetu; 7. Zaštita privatnosti na internetu; 8. Čuvanje digitalnih podataka (Tabela 3 ).

Tabela 3. Rotacija komponenti matrice

\begin{tabular}{|c|c|c|c|c|c|c|c|c|}
\hline \multirow{2}{*}{$\begin{array}{l}\text { Zavisne } \\
\text { varijable }\end{array}$} & \multicolumn{8}{|c|}{ Komponente } \\
\hline & 1 & 2 & 3 & 4 & 5 & 6 & 7 & 8 \\
\hline V12 & ,701 &, 118 &, 046 & , 175 & ,192 & ,033 &, 129 &, 006 \\
\hline V11 & ,654 &, 046 & , 186 &,- 090 &,- 465 &,- 019 & ,149 &,- 017 \\
\hline V16 & ,632 & ,202 &,- 089 &, 127 &,- 097 & ,346 &,- 110 &, 042 \\
\hline V20 &,- 393 & , 134 &,- 138 & ,187 & ,218 & , 145 &, 056 & ,364 \\
\hline V8 &, 045 & ,732 & ,135 &,- 022 &,- 021 &, 074 &, 020 & ,069 \\
\hline V9 & 135 & ,639 & 173 & ,046 &, 087 &,- 097 & 247 &,- 058 \\
\hline V1 & ,278 & ,509 & ,229 &,- 064 &,- 016 &, 169 &,- 342 &,- 061 \\
\hline V2 &,- 070 & ,480 &, 038 & ,226 &,- 110 & ,346 &, 185 &,- 213 \\
\hline V7 & ,039 & 155 & ,757 & 022 &, 030 & 207 &, 025 & 037 \\
\hline V6 & , 103 & ,241 & ,720 & ,083 &,- 106 &,- 036 &,- 074 &, 128 \\
\hline V10 &, 188 & ,015 &, 502 & ,280 &, 149 &,- 099 & ,279 &,- 180 \\
\hline V21 &,- 051 & ,075 &,- 033 &,- 722 & ,200 &, 041 &, 143 & ,204 \\
\hline V24 &,- 032 &, 070 & ,095 &, 555 & , 198 & ,046 &,- 073 & ,303 \\
\hline V19 & ,322 & ,001 &,- 010 &, 532 & ,090 & , 192 & ,308 & ,294 \\
\hline V4 & ,013 & ,270 & ,346 & ,471 &,- 065 & ,243 &, 004 &,- 038 \\
\hline V14 & ,068 & 003 & ,002 &,- 006 & ,750 &,- 004 &,- 001 & ,073 \\
\hline V15 &, 073 &, 040 &,- 054 &, 024 & ,740 &,- 093 & ,059 &, 130 \\
\hline V5 &,- 102 &,- 066 &,- 002 &,- 020 & ,457 & ,376 &,- 349 &,- 116 \\
\hline V3 &,- 221 &,- 284 &, 260 &,- 104 & ,392 & , 106 & ,109 &,- 196 \\
\hline
\end{tabular}




\begin{tabular}{rrrrrrrrr} 
V18 &, 276 &, 268 &,- 007 &,- 012 &, 063 & $\mathbf{, 6 7 3}$ &, 148 &,- 085 \\
V23 &,- 079 &,- 008 &, 076 &, 328 &, 018 & $\mathbf{, 5 6 0}$ &,- 012 &, 043 \\
V22 &, 163 &,- 088 &, 250 &,- 243 &,- 173 & $\mathbf{, 5 2 3}$ &, 112 &, 305 \\
V17 &, 018 &, 136 &,- 019 &,- 140 &,- 034 &, 025 &, $\mathbf{6 9 9}$ &, 029 \\
V13 &, 303 &, 008 &, 167 &, 074 &, 112 &, 280 & $\mathbf{, 5 6 0}$ &,- 089 \\
V25 &,- 012 &,- 079 &, 067 &, 012 &, 076 &,- 028 &,- 011 &, $\mathbf{8 1 3}$ \\
\hline
\end{tabular}

\section{Diskusija rezultata istraživanja}

\subsection{Nasilje na internetu}

Digitalno nasilje sve je prisutnije i teže ga je sprečiti nego nasilje u stvarnom svetu. Iako izgleda virtuelno ipak se dešava, ali često ostaje skriveno. Sve ono što kod pojedinca izaziva osećaj omalovažavanja, nepoštovanja jeste čin nasilja i ne treba ga trpeti. Stvara se privid da osoba može na mreži komentarisati sve šta i kako želi i oseća, a da ne vodi računa o vređanju, diskiminaciji, pretnjama. Svako ima slobodu da komentariše, ali u skladu sa moralnim načelima i uz odsustvo diskriminacije po bilo kom osnovu.

$\mathrm{Na}$ osnovu rezultata prikazanih u Tabeli 4 možemo zaključiti da većina adolescenata: ne dobija preteće poruke na internetu; ne ostavlja uvredljive komentare na internetu; ne dobija seksističke komentare na internetu u velikoj meri; nema izraženu svest o posledicama neadekvatnog izlaganja sopstvene ličnosti na mreži.

Tabela 4. Zastupljenost nasilja na internetu

\begin{tabular}{lllll}
\hline Tvrdnje & Min & Max & M & sd \\
\hline Nisam dobijao/la sam preteće poruke preko interneta. & 1 & 5 & 4.27 & .08 \\
Ne ostavljam uvredljive komentare na internetu. & 1 & 5 & 4.50 & .07 \\
$\begin{array}{l}\text { Dobijao/la sam seksističke poruke preko interneta.* } \\
\text { Jednom postavljena fotografija na internetu nekoliko godina }\end{array}$ & 1 & 5 & 3.98 & .09 \\
kasnije može biti prepreka za dobijanje posla. & 1 & 5 & 3.28 & .10 \\
\hline
\end{tabular}

Legenda. *tvrdnja je obrnuto bodovana

\subsection{Privatnost $i$ internet}

Zaštita privatnosti na internetu je presudna za sprečavanje zloupotrebe i krađe identiteta. Rezultati u Tabeli 5 pokazuju da adolescenti ne zakazuju sastanke na slepo, ne koriste istu šifru na svojim nalozima na internetu u velikoj meri, ne prihvataju bilo koga na društvenim mrežama. Međutim, adolescenti ipak dozvoljavaju drugima da vide njihov profil na fejsbuku, čime ne štite svoju privatnost.

Tabela 5. Privatnost na internetu

\begin{tabular}{lllll}
\hline Tvrdnje & Min & Max & M & sd \\
\hline $\begin{array}{l}\text { Imam lična iskustva sa sastancima na slepo zakazanim preko } \\
\text { interneta.* }\end{array}$ & 1 & 5 & 4.16 & .08 \\
$\begin{array}{l}\text { Na svim nalozima koje imam na internetu (mejl, društvene } \\
\text { mreže) koristim istu šifru.* }\end{array}$ & 1 & 5 & 3.98 & .08
\end{tabular}


Na društvenim mrežama prihvatam sve osobe za prijateljstvo

bez obzira što ih ne poznajem.*

$5 \quad 4.05$

.08

Moj profil na društvenim mrežama je vidljiv svima.*

1

5

$\begin{array}{ll}3.55 & .09\end{array}$

Legenda. *tvrdnje su obrnuto bodovane

\subsection{Neopreznost na internetu}

Iz dobijenih rezulta prikazanih u Tabeli 6 može se zaključiti da su adolescenti obazrivi na internetu, odnosno da o svojim problemima ne razgovaraju sa nepoznatim ljudima preko interneta, ne otvaraju linkove koji su sumnjivi, odnosno nude neku nagradu, kao i da ne daju svoje šifre naloga drugima.

Tabela 6. Neoprezno ponašanje na internetu

\begin{tabular}{lllll}
\hline Tvrdnje & Min & Max & M & sd \\
\hline $\begin{array}{l}\text { O svojim ličnim problemima pričam sa nepoznatim ljudima preko } \\
\text { interenta.* }\end{array}$ & 1 & 5 & 4.64 & .06 \\
$\begin{array}{l}\text { Klikćem na linkove koji me obaveštavaju da sam dobila neku } \\
\text { nagradu ili novac.* }\end{array}$ & 1 & 5 & 4.60 & .05 \\
$\begin{array}{l}\text { Šifru svojih naloga na internetu (mejla, društvenih mreža) dajem } \\
\text { drugim ljudima.* }\end{array}$ & 1 & 5 & 4.66 & .06 \\
\hline
\end{tabular}

Legenda. *tvrdnje su obrnuto bodovane

\subsection{Obazrivost na internetu}

Obazrivost na internetu je zastupljena što pokazuju razultati u Tabeli 7, međutim, adolescenti smatraju da komentari postavljeni na mreži mogu da se izbrišu. Takav stav pruža mogućnost da se komentariše na način koji se želi, ali uvek treba imati na umu da se sve što radimo na mreži ne može u potpunosti izbrisati.

Tabela 7. Obazrivost na internetu

\begin{tabular}{lllll}
\hline Tvrdnje & Min & Max & M & sd \\
\hline $\begin{array}{l}\text { Umem da podesim svoje naloge na internetu tako da } \\
\text { sačuvam svoju privatnost. }\end{array}$ & 1 & 5 & 4.34 & .07 \\
$\begin{array}{l}\text { Svoje lične informacije (adresu, matični broj, broj telefona, } \\
\text { broj kreditne kartice) delim sa ljudima na internetu.* }\end{array}$ & 1 & 5 & 4.57 & .06 \\
$\begin{array}{l}\text { Lažno govorim o drugima preko interneta.* } \\
\begin{array}{l}\text { Kada jednom postavite komentar na internetu, društvenoj } \\
\text { mreži, blogu više ga ne možete izbrisati. }\end{array}\end{array}$ & 1 & 5 & 4.50 & .07 \\
\hline
\end{tabular}

Legenda. *tvrdnje su obrnuto bodovane

\subsection{Ugrožavanje bezbednosti na internetu}

Ugrožavanje sopstvene i tuđe bezbednosti na internetu može dovesti do posledica, te zato adolescenti ne treba da veruju u oglase na koje nailaze a koji nude laku zaradu, ili iza kojih ne stoje poznate organizacije i poslodavci. Kada koristimo tuđ računar, treba voditi računa da on ne pamti naše lozinke. Na internetu se ne treba 
predstavljati kao neko drugi, odnosno prikrivati svoj ili krasti tuđ identitet. Takođe, ne treba plasirati privatne slike, poruke, snimke drugih ljudi bez njihove dozvole.

\section{Tabela 8. Ugrožavanje sopstvene i tuđe bezbednosti}

\begin{tabular}{|c|c|c|c|c|}
\hline Tvrdnje & Min & $\operatorname{Max}$ & $\mathrm{M}$ & sd \\
\hline $\begin{array}{l}\text { Kada koristim tuđi računar za logovanje na svoj nalog odčekiram } \\
\text { opciju „,zapamti lozinku“. }\end{array}$ & 1 & 5 & 3.92 & .10 \\
\hline Smatram da na internetu ima lažnih oglasa. & 1 & 5 & 4.34 & .08 \\
\hline $\begin{array}{l}\text { Ne objavljujem slike ili video kipove drugih na internetu bez njihove } \\
\text { saglasnosti. }\end{array}$ & 1 & 5 & 3.48 & .11 \\
\hline Ne predstavljam se na internetu kao neko drugi. & 1 & 5 & 3.58 & .11 \\
\hline
\end{tabular}

Međutim, rezultati nisu zadovoljavajući (Tabela 8). Pokazalo se da adolescenti smatraju da na internetu ima lažnih oglasa, ali potrebno je podići svest adolescenata o plasiranju tuđih privatnih informacija mimo njihovog znanja, lažnom predstavljanju kao i zaštiti sopstvenih naloga kada ih koristimo na tuđim uređajima.

\subsection{Neiskrenost na internetu}

Kao i u životu, i na mreži nisu svi sagovornici iskreni, što smatraju i adolescenti. Međutim, većinu informacija koje čitaju na internetu adolescenti smatraju istinitim. Drugim osobama ne šalju se uvredljive stvari u šali (Tabela 9).

Tabela 9. Iskrenost i laž na interentu

\begin{tabular}{lllll}
\hline Tvrdnje & Min & Max & M & sd \\
\hline $\begin{array}{l}\text { Drugim osobama šaljem uvredljive i strašne stvari, iako se samo } \\
\text { šalim.* }\end{array}$ & 1 & 5 & 4.12 & .09 \\
Informacije koje čitam na internetu smatram istinitim. & 1 & 5 & 3.64 & .07 \\
Na mreži su svi sagovornici iskreni.* & 1 & 5 & 4.35 & .06 \\
\hline
\end{tabular}

Legenda. *tvrdnje su obrnuto bodovane

\subsection{Zaštita privatnosti na internetu}

Sopstvenu privatnost treba zaštiti, ali je na osobi da izabere u kojoj meri će svoje intimne stvari plasirati javnosti. Važno je znati koje su posledice izlaganja javnosti.

Tabela 10. Zaštita sopstvene privatnosti

\begin{tabular}{lllll}
\hline Tvrdnje & Min & Max & M & sd \\
\hline $\begin{array}{l}\text { Moji vršnjaci objavljuju moje video klipove ili slike na internetu bez } \\
\text { moje saglasnosti.* }\end{array}$ & 1 & 5 & 4.23 & .08 \\
$\begin{array}{l}\text { Na društvenim mrežama često postavljam na kojim mestima volim da } \\
\text { provodim vreme.* }\end{array}$ & 1 & 5 & 4.05 & .08 \\
\hline
\end{tabular}

Legenda. *tvrdnje su obrnuto bodovane 
Adolescenti ne plasiraju tuđe privatne informacije u vidu slika i klipova javnosti bez saglasnosti tih osoba, i uglavnom ne postavljaju na kojim mestima provode vreme, odnosno ne taguju sebe na društvenim mrežama (Tabela 10).

\section{8. Čuvanje digitalnih podataka}

Rezultati istraživanja su pokazali da adolescenti ne prave rezervne kopije datoteka iz računara kako bi sačuvali važne fajlove, odnosno dokumente (Tabela 11).

Tabela 11. Informatička pismenost

\begin{tabular}{lllll}
\hline Tvrdnje & Min & Max & M & sd \\
\hline Pravim rezervne kopije datoteka iz računara. & 1 & 5 & 3.11 & .09 \\
\hline
\end{tabular}

Svest o čuvanju važnih digitalnih podataka na još nekom mestu izuzev kompjutera ili uređaja sa kojih smo ih pregledali i sačuvali, još uvek nije u dovoljnoj meri razvijena kod adolescenata.

\subsection{Kvalitet života adolescenata, bezbednost na internetu i digitalna kompetentnost}

Pošli smo od pretpostavke da stav o kvalitetnijem životu uz upotrebu interneta, kao i stav o tome da li su bezbedni dok koriste internet mogu uticati na njihovu digitalnu kompetentnost. Međutim, rezultati prikazani u Tabeli 12 su pokazali da postoje statistički značajne razlike među adolescentima samo u nekim stavovima. Adolescenti koji smatraju da im je život kvalitetniji kada koriste internet, na društvenim mrežama prihvataju i osobe koje ne poznaju, za razliku od adolescenata koji kvalitet života ne dovode u vezu sa upotrebom interneta. Pokazalo se da se adolescenti koji smatraju da im život nije kvalitetniji uz internet izjašnjavaju da jednom postavljena fotografija ne može biti prepreka za dobijanje posla u budućnosti. Ovim se implicira da adolescenti nisu svesni mogućih rizika postavljanjem fotografija koje mogu biti kompromitujuće, u vremenu kada je poslodavcu život potencijalnih radnika dostupan na društvenim mrežama. Može se zaključiti da adolescenti koji ne smatraju da je život kvalitetniji uz internet možda ne poznaju pravi način njegove upotrebe kao i rizike koje sa sobom nosi, što mogu biti hipoteze za neko novo istraživanje.

Tabela 12. Uticaj stava o kvalitetu života i bezbednosti na internetu na digitalnu kompetentnost

\begin{tabular}{|c|c|}
\hline Tvrdnje & $\chi^{2}$ \\
\hline Na društvenim mrežama prihvatam sve osobe za prijateljstvo bez obzira što ih ne poznajem. & $10,71^{*}$ \\
\hline $\begin{array}{l}\text { Jednom postavljena fotografija na internetu nekoliko godina kasnije može biti prepreka za } \\
\text { dobijanje posla. }\end{array}$ & $18,52 * *$ \\
\hline Umem da podesim svoje naloge na internetu tako da sačuvam svoju privatnost. & $12,00^{*}$ \\
\hline $\begin{array}{l}\text { Svoje lične informacije (adresu, matični broj, broj telefona, broj kreditne kartice) delim sa } \\
\text { ljudima na internetu. }\end{array}$ & $11,69^{*}$ \\
\hline
\end{tabular}

Legenda. ${ }^{* *} \mathrm{p}=.01 ;{ }^{*} \mathrm{p}=.05$ 
Međutim, s druge strane rezultati su pokazali da pozitivan stav o povezanosti kvaliteta života $\mathrm{i}$ interneta ne utiče na obazrivost deljenja ličnih podataka sa drugima na internetu, što ukazuje na nedovoljno znanja o zaštiti privatnosti na mreži. Obazriviji su adolescenti koji ne povezuju internet sa kvalitetom svog života. To nam govori da je potrebno studioznije ispitivanje uticaja drugih faktora na ponašanje adolescenata na internetu. Rezultati su pokazali da više adolescenta negativnog stava o kvalitetnijem životu uz upotrebu interneta ne ume da zaštiti svoju privatnost na internetu, za razliku od ostalih adolescenata (Tabela 12). Na osnovu svega možemo zaključiti da je adolescente potrebno osvestiti, odnosno preneti im znanje o dobrim i lošim stranama virtuelnog sveta, a njihov izbor je da li će i u kojoj meri koristiti internet kako bi unapredili i upotpunili svoj život.

\section{Zaključak i pedagoške implikacije}

Svaki adolescent treba da zna kako da se zaštiti na internetu, ali i kako da kreira svoj digitalni identitet, odnosno digitalnu reputaciju. Kada postane žrtva ili svedok sajber nasilja bilo koje vrste mora da poštuje sebe, izbori se, odnosno prijavi nasilje. Vilard (Willard, 2007) ističe da su zamke komunikacije preko mreže osećaj da u stvari ne povređujemo nekog ako se to dešava u virtuelnom svetu, a ne licem u lice; stav da ne možemo biti uhvaćeni ako činimo nasilje preko mreže; sloboda govora gde se sme reći sve na način koji se želi, bez obazrivosti da to može povrediti druge; stvaranje mulitiidentiteta, onlajn i stvarnog, gde se osoba poziva na onlajn identitet kada čini nedozvoljene stvari pravdajući se; shvatanje života na mreži kao igru i zabavu.

Prikazali smo deo rezultata opsežnijeg istraživanja o bezbednosti adolescenata na internetu. Možemo zaključiti da adolescenti pokazuju pozitivne stavove, odnosno da ne čine nasilje na internetu, da su oprezni na internetu, obazrivi, ne ugrožavaju sopstvenu i tuđu bezbednost, smatraju da na mreži ima i laži i iskrenosti. Percepcija kvalitetnijeg života i bezbednosti uz upotrebu interneta ne utiče na njihove stavove o ponašanju u sajber prostoru. Međutim, potrebno je ukazati na posledice neadekvatnog izlaganja sopstvene ličnosti na mreži, vidljivosti svog profila na društvenim mrežama drugima, ostavljanja komentara na mreži, objavljivanju slika ili video-kipova drugih na internetu bez njihove saglasnosti, lažnom predstavljanju i gubitku digitalnih dokumenata ukoliko ne pravimo rezervne kopije.

Upotreba medija u obrazovanju je u digitalnoj eri i više nego potrebna, a kako bi mediji bili adekvatno implementirani u obrazovno-vaspitni proces, treba da budu predmet istraživanja i valjane interpretacije podataka koji će se upotrebiti za unapređivanje digitalne prakse (Maksimović i Osmanović, 2018). Zabrana interneta je nemoguća i nehumana danas, a roditelji i nastavnici treba da pomognu deci u izboru digitalnih sadržaja. Odsustvo moralne i društvene odgovornosti čini upotrebu novih tehnologija rizičnom (Marković-Krstić i Milošević-Radulović, 2016: 205). Život u savremenoj digitalnoj zajednici protivreči zabrani upotrebe digitalnih alata i konzumaciji internet informacija. Podrazumeva etičke standarde prilikom upotrebe digital- 
nih medija. Kreiranje i implementcija programa prevencija u školama podrazumeva konstatnu edukaciju i obrazrivost, kao i evaluaciju efekata programa. Škola treba da kreira pravila upotrebe interneta; sprovodi istraživanja o digitalnom nasilju, edukuje učenike o digitalnoj sigurnosti, ukazuje na posledice digitalnog nasilja, upoznaje učenike sa timom kome se mogu obratiti kada se nasilje desi, sarađivati sa roditeljima i lokalnom zajednicom u prevenciji nasilja, sprovoditi vršnjačku medijaciju na temu prevencije nasilja (Couvillon \& Ilieva, 2011). Upotreba programa prevencije je pokazala uspešnost, te se zato treba insistirati na njihovoj primeni. KonRed (ConRed) program prevencije sproveden u Kordobi u Španiji, koji je podrazumevao obučavanje roditelja i nastavnika da spreče rizična ponašanja mladih, pokazao je da nakon njegove primene učenici postaju umešniji u kontrolisanju svojih privatnih podataka na internetu, kao i da je manje žrtvi i počinioca digitalnog nasilja. Takođe dolazi do osvešćivanja, odnosno razvoja empatije prema žrtvama. Školska klima je ovim programom unapređena, ali se pokazalo da je kod devojčica pojačan stah od digitalnog nasilja, na čemu treba dodatno raditi (Ortega-Ruiz et al., 2012).

Buduća istraživanja treba da se fokusiraju na konkretne načine delovanja preterane upotrebe digitalnih tehnologija, odnosno kako ona utiče na naše ponašanje $i$ život u zajednici. Država i njene isntitucije treba da rade na digitalnoj kulturi. Deci treba omogućiti pristup kvalitetnim onlajn resursima, s akcentom na kreiranje kvalitetnih digitalnih sadržaja namenjenih njima. Zaštita na internetu treba da bude prilagođena uzrastu i zrelosti deteta. Privatnost i identitet dece treba zaštititi. Potrebno je upoznati decu sa rizicima koje sa sobom nosi onlajn komunikacija, kao i da sve što se na internetu podeli više nije privatno već javno. Tolerancija na mreži treba da se razvija i neguje. Etički standardi treba da postoje kako bi se sprečilo neovlašćeno korišćenje tuđih podataka. Privatne i javne institucije treba da edukuju roditelje o načinima stvaranja bezbednog onlajn prostora (UNICEF, 2017).

\section{Literatura}

Bawden, D. (2001). Information and digital literacies: a review of concepts. Journal of Documentation, vol. 57, no. 2, pp. 218-259.

Bogavac, Lj. i Popadić, D. (ur.) (2013). Tagged priručnik za zaštitu dece i mladih od sajber nasilja i primenu u redovnom nastavnom programu osnovnih $i$ srednjih škola. Retrived February 12, 2019 from: http://kliknibezbedno.rs/files/materijali/ITC\%20 -\%20Tagged\%20Manual\%202013.pdf

Couvillon, A. M. \& Ilieva, V. (2011). Recommended Practices: A Review of Schoolwide Preventative Programs and Strategies on Cyberbullying. Preventing School Failure, 55 (2), 96-101. DOI: 10.1080/1045988X.2011.53946

Goodman, S. (2003). Teaching Youth Media: A Critical Guide to Literacy, Video Production, and Social Change. New York: Teachers College Press.

Gross, E. F. (2004). Adolescent Internet use: What we expect, what teens report. Applied Developmental Psychology, 25, pp. 633-649.

Gutiérrez, A. \& Tyner, K. (2012). Media Education, Media Literacy and Digital Compe- 
tence. Educación para los medios, alfabetización mediática y competencia digital. Comunicar, Scientific Journal of Media Education, 19 (38), pp. 31-39. DOI: 10.3916/ C38-2012-02-03

Hrnjić-Kuduzović, Z., Terzić, N. i Delić, A. (2016). Razumijevanje informacijskih potreba i navika internetske generacije. Izveštaj o kvalitativnom ispitivanju. U: Hrnjić-Kuduzović, Z. (Ur.), Informisanje internetske generacije (str. 69-82). Tešanj; Vogošća: Planjax komerc.

Hrnjić-Kuduzović, Z. (2016). Percepcija vjerodostojnosti online informacija među internetskom generacijom. Izveštaj o kvantitativnom ispitivanju. U: Hrnjić-Kuduzović, Z. (Ur.), Informisanje internetske generacije (str. 83-120). Tešanj; Vogošća: Planjax komerc.

Ilomäki, L., Kantosalo, A., \& Lakkala, M. (2011). What is digital competence? In Linked portal. Brussels: European Schoolnet Retrieved February 15, 2019 from: http://inked.eun.org/web/guest/in-depth3

Kellner, D. \& Share, J. (2009). Critical Media Education and Radical Democracy. In: Apple, W.M., Au,W. \& Gandin, A.L. (Eds), The Routledge International Handbook of Critical Education (pp. 281-295). New York: Routledge.

Kostadinović, M. i Jovanović, A. (2017). Safety of Adolescents in the Digital Age. U: Pralica, D. i Šinković, N. (ur). Digitalne medijske tehnologije i društveno-obrazovne promene 7 (str. 111-123), Novi Sad: Filozofski fakultet.

Kuzmanović, D., Lajović, B., Grujić, S. i Medenica, G. (2016). Digitalno nasilje - prevencija i reagovanje. Beograd: Ministarstvo prosvete Republike Srbije i Pedagoško društvo Srbije.

Maksimović, J. i Osmanović, J. (2018). Kvantitativna istraživanja medija u obrazovanju. Godišnjak Pedagoškog fakulteta u Vranju, 9 (1), 123-136.

Marković-Krstić, S. i Milošević-Radulović, L. (2016). Humanistička dimenzija obrazovanja mladih u kontekstu savremenih društvenih promena. Niš: Filozofski fakultet.

Nešić, S. (2011). Izveštaj zaštitnika građana i panela mladih savetnika. Zaštita dece od nasilja $u$ školama. Beograd: Zaštitnik građana; Interprint.

Ortega-Ruiz, R., Del Rey, R. \& Casas, A.J. (2012). Knowing, Building and Living Together on Internet and Social Networks: The ConRed Cyberbullying Prevention Program. International Journal of Conflict and Violence, 6 (2), pp. 303-313.

Peter, J., Valkenbzrg, M.P. \& Schouten, P.A. (2005). Developing a Model of Adolescent Friendship Formation on the Internet. CyberPsyhology \& Behaviour, 8 (5), pp. 423430.

Popadić, D. i Kuzmanović, D. (2013). Korišćenje digitalne tehnologije, rizici i zastupljenost digitalnog nasilja među učenicima u Srbiji. Retrived February 12, 2019 from: http://sbn.mpn.gov.rs/clientpub/uploads/Digitalno\%20nasilje-Izvestaj\%202013.pdf

Poter, Dž. (2011). Medijska pismenost. Beograd: Clio.

Pravilnik o protokolu postupanja u ustanovi u odgovoru na nasilje, zlostavljanje $i$ zanemarivanje. (2010). Službeni glasnik Republike Srbije, br. 30/2010.

Rideout, V., Foehr, U. G. \& Roberts, D. F. (2010). Generation M2: Media in the Lives of 8-18 Year-olds. Washington: Kaiser Family Foundation. Retrieved February 14, 2019 from: https://www.kff.org/other/event/generation-m2-media-in-the-lives-of/ 
Slonje, R. \& Smith, P. K. (2008). Cyberbullying: Another main type of bullying? Scandinavian Journal of Psychology, 49, 147-154.

Smith, K. P, Mahdavi, J., Carvalho, M., Fisher, S., Russell, S. \& Tippett, N. (2008). Cyberbullying: its nature and impact in secondary school pupils. Journal of Child Psychology and Psychiatry, 49 (4), pp 376-385. DOI: 10.1111/j.1469-7610.2007.01846.x

UNICEF (2016). Istraživanje o nivou svesti o potencijalnim internet rizicima i zloupotrebama među roditeljima dece uzrasta 8 do 17 godina. Retrieved February 13, 2019 from: http://www.unicef.rs/files/Istrazivanje $\% 20 \mathrm{o} \% 20$ nivou $\% 20$ svesti\%20roditelja\%20o\%20rizicima\%20od\%20zloupotrebe\%20dece\%20na\%20internetu.pdf

UNICEF (2017). Deca u digitalnom svetu. Retrieved February 13, 2019 from: https:// www.unicef.org/serbia/sites/unicef.org.serbia/files/2018-05/deca-u-digitalnom-svetu.pdf

Willard, N. (2007). Cyberbullying and cyberthreats: Responding to the challenge of online social aggression, threats, and distress. Champaign, IL, US: Research Press.

Ybarra, M. L. \& Mitchell, K. J. (2007). Prevalence and Frequency of Internet Harassment Instigation: Implications for Adolescent Health. Journal of Adolescent Health, 41, pp. 189-195.

Zakon o osnovama sistema obrazovanja i vaspitanja. (2018). „Službeni Glasnik RS - Prosvetni glasnik“ br. 88/2017, 27/2018.

\title{
DIGITAL COMPETENCE OF ADOLESCENTS
}

\author{
Aleksandra Jovanović \\ University of Nis, Faculty of Philosophy, Department of Pedagogy (PhD student) \\ Maja Kostadinović \\ University of Nis, Faculty of Philosophy, Department of Communication and Jour- \\ nalism (PhD student)
}

Summary: This paper considers the significance of digital competences of adolescents. Contemporary life is marked with technical and technological solutions that are a part of every aspect of people's lives and work. In order to use the internet and its content, each user must have at least minimum knowledge which will enable them to cope in a digital world. 'The most democratic medium' allows the opportunity for everyone to see and place different content at any time. The internet has become a powerful weapon for different influences of propaganda. With the analysis of 222 adolescents' attitudes we take into consideration whether the use of the internet increases the quality of their lives, how developed their awareness of the safety of the internet is, and if they are digitally competent. The presence of insulting on the internet, caution, protection of privacy, endangering safety, spreading misinformation, respecting others, endangering privacy, and precaution are being considered. The results have shown that adolescents think that the internet increases the quality of their lives as well as that they are safe on the internet. All of this confirms the fact that adolescents are 'digital natives', as well as that they possess digital competences. However, apart from this, 
it is necessary to implement a program of media education that will develop critical awareness and enable adolescents to recognize various attempts of placing ideas, influencing thinking and prompting actions that may endanger the rights of other people through content.

Key words: digital competences, internet safety, digital violence, critical pedagogy, prevention.

\section{Citiranje članka:}

Jovanović, A. i Kostadinović, M. (2019). Digitalna kompetentnost adolsecenata. Godišnjak za pedagogiju, 4(1), 85-100 